\title{
FACTOR ANALYSIS THAT FORMS EXPECTATION OF GUEST HOUSE GUEST EXPERIENCE
}

\author{
Renava Aprillea $^{(1)}$, A.H.G. Kusumah ${ }^{(2)}$, Reiza Miftah Wirakusuma ${ }^{(3)}$ \\ (1)(2)(3) Program Studi Manajemen Resort \& Leisure \\ Universitas Pendidikan Indonesia \\ renaaprillea2@gmail.com
}

\begin{abstract}
The expectation of Guest House guest experience is the expectation of the guest perspective on what the Guest House will occupy. If the manager can fulfill the guest's expectation, it can grow the guest's loyalty and allows being repeater guest. The purpose of this study is to determine what are the factors that forms expectations of Guest House guest experience. This research uses quantitative method with factor analysis. In this study shows that there are four factors forming expectations of Guest House guest experience, spesifically on the youth travellers.
\end{abstract}

Keywords: Factor Analysis, Customer's Expectation, Experienc, Guest House.

\section{INTRODUCTION}

The purpose of this study is to find out and analyze the factors that forming the expectations of the experience expected by guests during their stay at the Guest House. The purpose of choosing a Guest House as research material because of the development of youth travelers and budget travelers or back packers in the tourism world. With a limited budget, the Guest House is very appropriate as an accommodation for budget travelers, because it does not require a large fee to stay.

Arief, Abd. Rachman (2005, pp. 13) stated that Guest House is one of the types of assets used by companies, government/private agencies, which are intended for guests who stay and get dining, drinking and service facilities provided free of charge and borne by the company/institution that invited them. But if the Guest House is owned by a private company or individual that is open to the public, then the feature is the same as the hotel, namely aiming to gain profit (profit motive) only the service is simple.
According to Knutson et al (2009), the core of experience is internal and individual. This requires the involvement or participation of the people involved. In this study, the people involved were prospective guests who had never stayed at Guest House and Guest House guests. Haywood (in Nasution, 2008) argued that the Guest House must focus on developing service quality so that guests' needs and expectations can be fulfilled. Consumer expectations are everything that consumers believe about what they get related to the performance of a particular product or service. (Anderson dan Chambers, 1985, in Maxmanroe.com).

The guest experience obtained is intangible, which means that it can only be felt by guests during their stay at the Guest House. Experience is difficult to measure, because it is individual and personal. Need to know that each person has their own background, ethics, beliefs, and thoughts. The rate of expansion for each person is different. If the factors that forming the expectations of a guest experience can be achieved, then it is possible that loyal guests will become repeater guest. 


\section{LITERATURE REVIEW}

\section{Guest Experience Expectations}

Sutisna (in Maxmanroe.com) argues that expectation is an individual's previous beliefs about things that should occur in certain situations. It can also be understood that expectations are everything that consumers believe about what they will get related to the performance of a particular product or service (Anderson dan Chambers, 1985, in maxmanroe.com). Fleming and Levie (in maxmanroe.com) also argues that expectations are all the desires, hopes, and ideals of a thing that wants to be achieved with behavior and real action. It can be concluded that expectations are expectations that will be obtained from something they will get.

Jennings and Nickerson (2006, pp. 82) argues that an experience is not a brief matter, but a complex process, which involves many parties, develops over time, and maintains old values into the future. Not everyone has the same experience (Lounsbury and Polik, in Jennings, 2006). Because experience comes from interactions or a series of interactions between consumers, the environment, and providers (O'Sullivan and Spangler, in Jennings, 2006). This interaction leads to reactions where consumers are satisfied with what they have gotten (LaSalle and Britton, in Jennings, 2006) also not easily forgotten (Pine and Gilmore, in Jennings, 2006).

According to Holbrook and Hirschman (in Jennings, 2006), experience is part of the behavior of customers or guests that relates to emotions, fantasies, and the different perspectives of each guest. Pine and Gilmore (in Jennings, 2006) also define experience as a different economic value for guests so that it can be sustainable and easy to remember, besides the good experience gained by guests can encourage guests to share or share their experiences with others. Experience is a combined result that influences a guest emotionally physically, intellectually, and spiritually (Mossberg, in Cetin, 2013). Oh, Fiore, and Jeoung (in
Cetin, 2013) argue that experience is a fun, interesting, and exciting thing for guests involved and as consuming one type of accommodation business. Walls (in Cetin, 2013) make it clear that personal experiences also involve the perception and participation of guests, while also involving guests emotionally so that guests are not reluctant to share their experiences with others and remember them for quite a long time, in other words it is difficult to forgotten.

It can be concluded that the expectations of experience are guests' perspective expectations regarding things obtained from tourist destinations or accommodation services that he will occupy. If the manager can fulfill the expectations of guest guesting, it can foster guest loyalty. By giving discounts, delivering the right service, also the nuances and themes provided by the accommodation services can have a very good impact so that guests become loyal. So that it does not rule out the possibility that guests will become repeater guest.

\section{Dimensions of Guest Experience Expectations}

Knutson et al (2009) found that there are four dimensions of guest experience expectations in one type of accommodation, namely:

\section{Benefit}

The purpose of this benefit is the benefits of what guests get during their stay in one type of accommodation. According to his research, this dimension is the most important dimension for the experience of guests staying in one type of accommodation. Things that include benefits or benefits such as security, location, availability of fitness center, amenities, and room service.

\section{Convenience}

Convenience is the second most important dimension of a guest experience in one type of accommodation. This dimension involves guest rooms and accommodation facilities, availability of amenities, and 
convenience in booking rooms and available facilities. Convenience is included in the ability to make online bookings, fast checkin and check-out services, and fast room service.

\section{Incentive}

This dimension is a factor that makes guests have a plus point for the type of accommodation they occupy. Incentive can also be a marketing strategy, such as room upgrades, adding an a la carte menu to special dinners, and providing exclusive recreational packages.

\section{Environment}

This dimension is in line with the tangible dimension of Zeithaml et al (in Knutson, 2009). Guests want their temporary residence environment (accommodation) to entertain, provide a sense of enthusiasm, motivation, and interactive. They also want the environment or atmosphere of accommodation that has its own theme, so that's where they get experience. An example is the hotel or Guest House they live in has a forestry theme with tree decorations like they are in the woods.

\section{METHOD}

The research method used in this study is descriptive with a quantitative approach, then the method of data collection is by distributing questionnaires. The type of scale made in this study is the Likert scale. Descriptive research is research that aims to make a description of a social/natural phenomenon systematically, factually, and accurately (Wardiyanta, 2006, pp. 5), while the quantitative approach according to Indrawan et. al (2014, p. 51) is a form of scientific research that examines one problem of a phenomenon, and looks at possible links or relationships between variables in the problem set. While to analyze the factors forming expectations of guest experience, factor analysis techniques are used using the SPSS 20.00 application.

Ghozali (2005, pp. 253) explains that factor analysis aims to summarize the original variables to produce new factors. In factor analysis through a series of assumption tests. The first step is to test the variables that aim to determine whether or not the variables are feasible to proceed to the next stage, namely by looking at the results of the KMO and Bartlett tests and MSA measurements, carrying out the factoring process, rotating, and interpreting the formed factors.

The sample in this study is as many as 200 respondents who have never and never stayed at a Guest House. The sampling process was carried out by non-probability convenience sampling.

\section{HASIL DAN PEMBAHASAN}

As mentioned earlier, the purpose of this study is to know and analyze what are the factors that forming the expectations of the experience expected by guests during their stay at the Guest House.

The beginnings of this study were the results of general respondents totaling 200 respondents. After doing the factor analysis process, there are three new factors. But looking at the variables that make up the three new factors is considered not to show the results of specific factors. So from that the writer will process the data again using the control variable method.

\section{Factor Analysis of All Respondents}

The total number of respondents was 200 respondents, both those who had and had never stayed in a Guest House. After the results of the data from 200 respondents were processed through factor analysis using SPSS 20.0 software it resulted in three factors forming guest experience expectations.

Table 1. Three Forming Factors of Guest House Guest Experience Espectations $(\mathbf{N}=\mathbf{2 0 0})$

\begin{tabular}{ccc}
\hline \multirow{2}{*}{ Factor and Variable } & \multicolumn{2}{c}{ Factor Loading } \\
\cline { 2 - 3 } & $\mathbf{1}$ & $\mathbf{2}$ \\
\hline Amenities, Security, and Accessibility Factors (12 variables) \\
\hline \multicolumn{2}{c}{ Social environment security of the Guest House } &, 839 \\
\hline
\end{tabular}




\begin{tabular}{|c|c|c|c|}
\hline \multirow{2}{*}{ Factor and Variable } & \multicolumn{3}{|c|}{ Factor Loading } \\
\hline & 1 & 2 & 3 \\
\hline $\begin{array}{l}\text { Security access or path when heading to the Guest } \\
\text { House }\end{array}$ & ,773 & & \\
\hline Comfort of guest rooms & ,754 & & \\
\hline $\begin{array}{l}\text { Conveninece of access or path when heading to the } \\
\text { Guest House }\end{array}$ & ,723 & & \\
\hline Guest House management services for guests & ,696 & & \\
\hline Security during activities in the Guest House & ,682 & & \\
\hline Availability of Guest House facilities & ,681 & & \\
\hline $\begin{array}{l}\text { Prices of guest rooms are in accordance with the } \\
\text { facilities offered }\end{array}$ &, 681 & & \\
\hline $\begin{array}{l}\text { The arrangement of Guest House facilities and } \\
\text { amenities in the guest rooms }\end{array}$ & ,674 & & \\
\hline Availability of information services & ,663 & & \\
\hline Availability of guest room amenities & 613 & & \\
\hline Convenience in the process of booking a room & 608 & & \\
\hline \multicolumn{4}{|l|}{ Promotion Factor ( 5 variables) } \\
\hline $\begin{array}{l}\text { Suitability of employee uniforms with Guest House } \\
\text { themes }\end{array}$ & &, 768 & \\
\hline An entertaining environment for guests & & ,756 & \\
\hline $\begin{array}{l}\text { Atractiveness of the environment around the Guest } \\
\text { House }\end{array}$ & & ,756 & \\
\hline Guest House has a promo coupon & & ,711 & \\
\hline Interesting theme or interior design for guests & & ,694 & \\
\hline \multicolumn{4}{|l|}{ Communication Factor } \\
\hline $\begin{array}{l}\text { Interaction between guests and the Guest House } \\
\text { manager }\end{array}$ & & & ,786 \\
\hline $\begin{array}{l}\text { Interaction between guests and the community } \\
\text { around the Guest House }\end{array}$ & & & ,769 \\
\hline $\begin{array}{l}\text { Enjoy time with family or friends while in the Guest } \\
\text { House }\end{array}$ & & &, 584 \\
\hline
\end{tabular}

Based on the results of factor rotation analysis the data obtained through questionnaires distributed to 200 respondents who had stayed overnight or had never stayed in a Guest House, there were three new factors in the guest experience in one type of accommodation, namely a Guest House.

a. Amenities, Security, and Accessibility Factor

The first factor is the result of decomposition of benefit, convenience, and incentive factors belonging to Knutson et al (2009). This factor is named amenities, security, and accessibility because the variables incorporated in this factor contain elements of comfort, security, and accessibility obtained by guests while staying at a Guest House.

b. Promotion Factor

The second factor is the result of decomposition of the incentive and environment factors of Knutson et al (2009) which then stand alone into a new factor. The promotion factor consists of five variables that contain elements of the environment and marketing that are offered by managers to Guest House guests in order to attract guests. Referring to research by Hua et al (2009), there is a promotion factor which consists of variable differences in exterior and interior design, and special discounts for 
guests. Hua et al (2009) revealed that by having an exterior and interor design that is a distinctive feature and superiority for the Guest House itself, it can be a attractor and form of promotion for guests to stay at the Guest House.

\section{c. Communication Factor}

The third factor is a description of the social interaction factor belonging to Jennings et al (2006). The variable that forms the third factor is the same as the variables that form the social interaction factor, namely the interaction between guests and Guest House managers, interactions between guests and the community around the Guest House, and enjoying time with family or friends while in a Guest House. The interaction between guests and Guest House managers and the surrounding community occurs because guests of the Guest House want to have new experiences in interacting with the natives around the Guest House. The time enjoyed by family or friends while at the Guest House is because of the togetherness in acting during the Guest House.

\section{Factor Analysis of Youth Traveller}

Sugeng A. Y (2007) suggests that control variables are variables that need to be controlled, maintained, or randomized in such a way that their influence is neutralized, issued or equated for all conditions. Wahyu Widhiarsono (2011) argues that using outcome control variables better explain the phenomenon optimally because other variables that also influence dependent variables, the effect becomes interrupted.

There are 2 types of control variables namely sample control and statistical control. The author uses sample variables, which is done by equating the sample or respondent research (Wahyu Widhiarso, 2011). The sample used according to the factors of the demographic characteristics of the respondents, namely in terms of the respondents' last education. There were 125 respondents who were middle to high school education (junior and senior high school) and 75 respondents who were tertiary education (D3, S1, and S2). After being compared, the writer will use data from 125 respondents with the latest middle to high school education.

Table 2. Four Forming Factors of a Youth Traveler Experience Expectations at a Guest House ( $\mathbf{N}=125)$

\begin{tabular}{|c|c|c|c|c|}
\hline \multirow{2}{*}{ Factor and Variable } & \multicolumn{4}{|c|}{ Faktor Loading } \\
\hline & 1 & 2 & 3 & 4 \\
\hline \multicolumn{5}{|l|}{ Amenities Factor (7 variables) } \\
\hline Availability of Guest House facilities & ,802 & & & \\
\hline Availability of information services & ,748 & & & \\
\hline Availability of guest room amenities & ,647 & & & \\
\hline Comfort of guest rooms & ,624 & & & \\
\hline $\begin{array}{l}\text { Guest House management services for } \\
\text { guests }\end{array}$ &, 539 & & & \\
\hline $\begin{array}{l}\text { Prices of guest rooms are in accordance } \\
\text { with the facilities offered }\end{array}$ &, 517 & & & \\
\hline $\begin{array}{l}\text { The arrangement of Guest House } \\
\text { facilities and amenities in guest rooms }\end{array}$ &, 514 & & & \\
\hline \multicolumn{5}{|l|}{ Promotion Factor ( 5 variables) } \\
\hline $\begin{array}{l}\text { Suitability of employee uniforms with } \\
\text { Guest House themes }\end{array}$ & & ,774 & & \\
\hline Guest House has a promo coupon & & ,748 & & \\
\hline
\end{tabular}




\begin{tabular}{|c|c|c|c|c|}
\hline \multirow{2}{*}{ Factor and Variable } & \multicolumn{4}{|c|}{ Faktor Loading } \\
\hline & 1 & 2 & 3 & 4 \\
\hline $\begin{array}{l}\text { Atractiveness of the environment around } \\
\text { the Guest House }\end{array}$ & &, 726 & & \\
\hline $\begin{array}{l}\text { Interesting theme or interior design for } \\
\text { guests }\end{array}$ & &, 716 & & \\
\hline An entertaining environment for guests & & 677 & & \\
\hline \multicolumn{5}{|c|}{ Security and Accessibility Factors (4 variables) } \\
\hline $\begin{array}{l}\text { Security access or path when heading to } \\
\text { the Guest House }\end{array}$ & & & ,802 & \\
\hline $\begin{array}{l}\text { Conveninece of access or path when } \\
\text { heading to the Guest House }\end{array}$ & & & ,791 & \\
\hline $\begin{array}{l}\text { Social environment security of the Guest } \\
\text { House }\end{array}$ & & &, 611 & \\
\hline $\begin{array}{l}\text { Security during activities in the Guest } \\
\text { House }\end{array}$ & & &, 580 & \\
\hline \multicolumn{5}{|l|}{ Communication Factor (4 variables) } \\
\hline $\begin{array}{l}\text { Interaction between guests and the } \\
\text { community around the Guest House }\end{array}$ & & & & ,764 \\
\hline $\begin{array}{l}\text { Enjoy time with family or friends while in } \\
\text { a Guest House }\end{array}$ & & & & ,706 \\
\hline $\begin{array}{l}\text { Interaction between guests and Guest } \\
\text { House managers }\end{array}$ & & & &, 673 \\
\hline $\begin{array}{l}\text { Convenience in the process of booking a } \\
\text { room }\end{array}$ & & & & ,462 \\
\hline
\end{tabular}

a. Amenities Factor

This first factor is the most important factor in the expectations of guest house guest experiences, named amenities, with an eigenvalue of 7.557. Named after amenities because the seven variables in it describe the comfort that guests expect when they stay at the Guest House as an experience. Amenities can also be interpreted by a meaning of "comfort".

b. Promotion Factor

Promotion has an eigenvalue of 2.481, which is the second rank after amenities as the most important factor in the expectations of Guest Guest gust experience. It's called promotion because the variables that make up the promotion factor contain environmental and marketing elements that can attract guests.

Referring to research by Hua et al (2009), there is a promotion factor which consists of variable differences in exterior and interior design, and special discounts for guests. Hua et al (2009) revealed that by having an exterior and interor design that is a distinctive feature and superiority for the Guest House itself, it can be a attractor and form of promotion for guests to stay at the Guest House. In addition, by giving special discounts or promos, it is also a guest expectation if the Guest House they occupy is not unique in terms of exterior and interior design.

c. Security and Accessibility Factors

The third sequence is the security and accessibility factors with the eigenvalues value of 1.374. This factor is named security and accessibility because the four variables contain elements of ease of access and security for guests. When guests stay at a Guest House, they not only expect security and convenience while in the Guest House, but also when heading to the Guest House.

In the research Hua et al (2009) stated that guest safety and security variables were included in the factors that he 
named the service quality factor. Similar to Knutson et al (2009), Hua et al (2009) also conducted their research on hotel case studies but were more directed towards budget hotels. Hua et al (2009) announced that guest security is fundamental to the continuity of the lodging business, because it is related to the safety and comfort of guests as well as the manager, so that it can have a positive effect on the value of guest experiences.

\section{d. Communication Factor}

The last factor is communication with the acquisition of an eigenvalue of 1.013. Called communication because the variables contain elements of communication during the guest stay at the Guest House. Variables enjoying time with family or friends while in a Guest House occur because of activities during the guests' stay at the Guest House. While guest interaction with the surrounding community and the interaction between guests and the manager, Nicolau and Mas (in Kusumah, 2017) revealed that this happened when guests sought opportunities to experience different experiences from new places and cultural values of the local community.

\section{CONCLUSION}

This study aims to find out and analyze what are the factors that shape the expectations of the experience expected by guests during their stay at the Guest House. After conducting research using a quantitative approach through questionnaires, a factor analysis is needed to summarize the original variable into a new factor or dimension.

Based on the results of the analysis and discussion on the research factors that shape the expectations of Guest House guest experiences, it can be concluded that the results of the factor analysis of 20 variables with a total sample of 200 respondents produced 3 factors that form the expectations of Guest House guest experiences. The one factor that contains 12 variables that contain elements of comfort, safety, and accessibility for guests. Factor two which contains 5 variables that contain environmental and marketing elements that can attract guests to stay at the Guest House. While factor three contains 3 variables that contain elements of communication. But when looking at the variables contained in one factor, it feels that factor one does not show specific results. So from that done again factor analysis by means of control variables.

\section{REFERENCE}

Arief, Abdul Rahman. (2005). Pengantar Ilmu Perhotelan dan Restoran. Yogyakarta: Graha Ilmu.

Ghozali, Imam. (2005). Aplikasi Analisis Multivariate Dengan Program SPSS. Semarang: Badan Penerbit Universitas Dipenogoro.

Hua, Wen et al (2009). Critical Success Factors and Customer Expectation in Budget Hotel Segment - A case Study of China. Journal of Quality Assurance in Hospitality \& Tourism, 10(1).

Indrawan, Rully et al. (2014). Metodologi Penelitian. Bandung: Refika Aditama.

Jennings, Gayle et al (2006). Quality Tourism Experiences. USA: Elsevier.

Knutson, Bonnie J et al (2009). Identifying the Dimension of the Guest's Hotel Experience. Journal of Cornell Hospitality Quarterly, 50(44).

Kusumah, A. H. G. (2017). A Conceptual framework of the Indonesian Resort Experience. The Hong Kong Polytechnic University.

Maxmanroe.com. (2018). Arti Ekspektasi: Pengertian Menurut Para Ahli serta Contohnya. [Online] Tersedia: https://www.maxmanroe.com/vid/umu m/arti-ekspektasi.html [Diakses pada 10 Mei 2018]

Nasution, Hanny N et al (2008). Customer Value in The Hotel Industry: What Managers Believe They Deliver and 
Journal of Indonesian Tourism, Hospitality and Recreation --- Volume 1, Nomor 2, Oktober 2018

What Customer Experience. Journal of Hospitality Management, 27.

Sugeng, A.Y. 2007. Dasar-Dasar Penelitian. Semarang: IKIP PGRI Semarang Press.

Wahyu Widhiarsono. (2011). Analisis Data Dengan Menggunakan Variabel Kontrol. [Online]. Tersedia di: widhiarso.staff.ugm.ac.id/fules/analisis datadenganmenggunakanvariabelkontr ol.pdf [Diakses pada 27 Juni 2018]
Wardiyanta. (2006). Metode Penelitian Pariwisata. Yogyakarta: Andi Offset. 